\title{
ENGLISH LEARNING MANAGEMENT IN THE ERA OF COVID-19 AT YOUNG LEARNER EDUCATION DEPARTMENT OF STKIP BINA INSAN MANDIRI
}

\author{
Norma Diana Fitri ${ }^{1}$, Sulistiyani ${ }^{2}$ \\ 1,2 STKIP Bina Insan Mandiri Surabaya \\ normadiana@stkipbim.ac.id, sulistiyani@stkipbim.ac.id
}

Received: Feb 15, $2021 \quad$ Revised: Feb 18, $2021 \quad$ Accepted: Feb 25, 2021

\begin{abstract}
As a Teaching and Education College, STKIP Bina Insan Mandiri, especially the English Learning management at young learner departement that has the courage to take steps to make online learning an opportunity to transform education. There are several steps that can be a collective reflection in improving the education system, especially related to online learning. Online learning usually, the instructors are in separate locations so that it requires an interactive telecommunication system to connect the two and the various resources needed in it. Electronic learning (e-learning) or online learning (online) is part of distance education that specifically combines electronic technology and technology for English learning.

In qualitative research here, it is related for making notes that really need to be done in order to make data analysis. Note making can be done while conducting interviews or while still conducting interviews, observations, and documentation. By using the documentation, method means collecting data by recording existing data.

Documents can be in the form of writings, pictures, or works of someone. So, online learning used as an effort to learn from lecturers, which is to focus more on efforts to transfer knowledge and skills for the students. This policy can also encourage students to be more innovative and creative in learning (students centered learning) especially at young learner departement STKIP Bina Insan Mandiri.

The physical encounter will not be abandoned even though the advancement of virtual and digital technology is getting thicker. Even though the Covid-19 outbreak will be last for a long time, we must think about patterns and methods of physical and social learning that are safe for everyone. The development of communication and digital technology has a significant role that academics can make the wide using to look a brighter future, especially at STKIP Bina Insan Mandiri, for Young Learner Departement in English Language teaching.
\end{abstract}

Keywords: English Learning management, Covid-19, young learner departement

\section{INTRODUCTION}

In the midst of the Covid-19 pandemic, the education system must be ready to take the leap to transform online learning for all students and by all educators. We are entering a new era to build creativity, hone students' skills, and improve self-quality with changes in systems, perspectives 
and patterns of our interactions with technology, especially in the academic environment of STKIP Bina Insan Mandiri Surabaya at English teaching of young learner education departement.

From these challenges, we must have the courage to take steps to make online learning an opportunity to transform our education. There are several steps that can be a collective reflection in improving the education system, especially regarding online learning:

When the Minister of Education and Culture issued Circular No. 3 of 2020 is concerning the Prevention of Covid-19 in the Education Unit on March 9, 2020; Minister of Health Circular No HK.02.01 / MENKES / 199/2020 on 12 March 2020; This choice must be taken to take effective preventive and mitigation measures for the outbreak which has now become a global pandemic.

Among the policies were taken to deactivate lecture activities in the collage environment to carry out sterilization and to carry out independent quarantine of students, lecturers and education personnel, including is not conducting meetings in public places as well as turning on lectures and online thesis / thesis guidance at STKIP Bina Insan Mandiri Surabaya for English teaching young learner departement.

The policy is active from March 16 to April 25 2020. Of course there were difficulties when this new policy was implemented. It was also explained that direct termination of face-toface did not mean that lectures and guidance were not carried out.

Online learning usually the instructors are in separate locations so that it requires an interactive telecommunication system to connect the two and the various resources needed in it. Electronic learning (e-learning) or online learning (online) is part of distance education that specifically combines electronic technology and internet-based technology.

The progress that occurs in the world of communication and information technology creates new opportunities and challenges in the world of education. New opportunities that have emerged include wider access to richer multimedia content, and the development of new learning methods that are no longer constrained by time and space. On the other hand, technological advances with a variety of digital innovations that continue to develop also present new challenges for education providers to continue to adapt education infrastructure with these new technologies. 
However, with the conventional lecture tradition, the choice of English learning by online from their respective residences is not easy. First, it requires device readiness and of course internet data packages that are still managed independently.

Second, not all lecturers and students are ready to operate the online learning system quickly, including preparing digital lecture materials well.

\section{METHODOLOGY AND DISCUSSION}

In this study, researcher used qualitative research methods with a descriptive qualitative approach. According to Moleong (2014: 6), qualitative research is research that has the intention

of understanding what phenomena are experienced by research subjects. Through this qualitative research, descriptive data were collected in the form of words, pictures, and not numbers (Sugiyono, 2015: 283). In qualitative research, humans play an important role as an instrument. In conducting research, the researcher himself becomes the main data collection instrument in the form of observation, interview, or document review.

\section{RESEARCH DATA}

The data in this study were collected by means of a natural setting with teaching English by online learning, especially in the young learner departement, with habituation in order to form Indonesian people with character that must be done in the real world, especially in the STKIP Bina Insan Mandiri Surabaya environment. When viewed from the data source, the following data collection is in the form of words that will be arranged in a narrative, where this will be able to clarify and strengthen the data obtained previously. Furthermore, when viewed in terms of data collection methods or techniques, researcher used the method of observation, interviews, and documentation.

\section{DATA COLLECTION TECHNIQUES}

In qualitative research, it is necessary to take notes as material in making data analysis. Making notes can be done at the time of conducting an interview or while still conducting interviews and observations. Mustafa (2009: 93). (3) Documentation comes from the word dokumen which means written goods. By using the documentation method means collecting data by recording existing data. According to Sugiyono (2012: 329) said that documents were records of events that have passed. Documents can be in the form of writings, pictures, or works of 
someone. So that English online learning can be used as an effort to learn from lecturers, which is to focus more on efforts to transfer knowledge and skills to students. This policy can also encourage students to be more innovative and creative in learning (student centered learning)

\section{DATA ANALYSIS TECHNIQUES}

Bogdan \& Biklen in Moleong (2014: 248) explained that in carrying out data analysis, of course, going through the process of collecting data in the field through field notes, reading or studying data, collecting it, sorting it out, and then thinking by making that data category, so the students, lecturers, and education staff, including are not holding meetings in public places as well as enabling online lectures and thesis / thesis guidance.

\section{VALIDITY CHECKING TECHNIQUE}

To test the validity of the data in the study, an extension of the observation and triangulation was used to test the accuracy of the data obtained from the study. In order to obtain complete data in the English learning. So that online learning hones the skills of students, and improves self-quality with changes in systems, perspectives and patterns of our interactions with technology, especially in the academic environment of STKIP Bina Insan Mandiri Surabaya of English teaching in young learner departement.

\section{CONCLUSION}

One of the things that universities can do to physically 'lockdown' lectures - of course temporarily - and maximize the 'open up' of other types of lectures by utilizing virtual and digital technology in teaching English at young learner departement of STKIP Bina Insan Mandiri environment.

The industrial revolution 4.0 allows us to carry out renewable initiatives to maximize the functions of communication, information transfer and knowledge. The world may be plague and squeezed by slowing growth, but the world of education must keep running in order to continue civilization.

The physical encounter will still not be abandoned even though the advancement of virtual and digital technology is getting thicker. Even though the Covid-19 outbreak will last a long time, we must think about patterns and methods of physical and social learning that are safe 
for everyone well. The development of communication and digital technology has a significant role that academics can use to make a brighter future in teaching English at young learner departement of STKIP Bina Insan Mandiri environment.

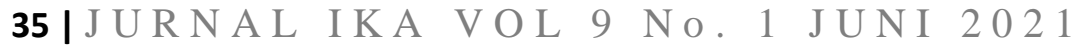




\section{DAFTAR PUSTAKA}

Almerico, G.M. (2014). Building Character through Literacy with Children's Literature. Research in Higher Education Journal, Vol. 26(1), pp. 1-13

Aryandini, S. Woro. (2000). Citra Bima Dalam Kebudayaan Jawa. Jakarta: UI-Press.

Byrum, J. L., Jarell, R., Munoz, Bastom M. (1992). The perceptions of teachers and administrators on the impact of the lesson study initiative. Louisville, KY: Jefferson County Public Schools. (ERIC Document Reproduction Service No. ED 467761)

Bogdan bikler, Pervin, L. A., \& John, O. P. (1997). Personality: Theory and Research (7th ed.). New York: John Wiley \& Sons, Inc.

Catherine Crosby. (2011). Lesson Study, Step by Step: How Teacher Learning Communicates Improve Instruction. HEINEMANN. Portsmouth. NH.

Moleoung,Miles, Mathew B., Huberman, A. Michael, \& Saldana, Johnny. (2014). Qualitative Data Analysis: A Methods Sourcebook. Thousand Oaks: SAGE Publication, Inc.

Podhorsky, C. and Moore, V. (2006). Issues in Curriculum: Improving Instructional Practice through Lesson Study. Http:///www.lessonstudy.net

Sugiyono, (2011). Metode Penelitian Pendidikan: Pendekatan Kuantitatif Kualitatif; dan $R \& D$. Bandung. Alfabeta.

Suwaji, bostSiswoyo, D.; Sulistyono, T.; Dardiri, A.; Rohman, A.; Hendrowibowo, L.; dan Sidharto, S. (2002). Ilmu Pendidikan. Yogyakarta: UNY Press 